\title{
Flypaper Effect: Fiscal Illusion and Bureaucratic Model
}

\author{
Hendra Kusuma \\ Faculty of Economy and Business, University of Muhammadiyah Malang \\ Email: hendraksm9@gmail.com
}

Received: August 5, 2016; Accepted: December 11, 2016; Published: March 2, 2017

Permalink/DOI: http://dx.doi.org/10.17977/um002v9i12017p027

\begin{abstract}
Fiscal decentralization as a delegation form of fiscal authority from the central government to the regional government is expected to accelerate the regional economic growth in accordance with the respective characters in each region. The overspreading potency in utilizing the transfer funds from the central government is more likely to be higher if the regional budget is not designed effectively and efficiently to support the acceleration of regional economic activities. This study aimed at investigating the influence of unconditional grant, regional revenue, gross regional domestic product, and population density towards the regional budget in East Java Province during the implementation of fiscal decentralization. Model specification used was an overview of regional budget, in which the flypaper effect was detected by comparing the coefficient of unconditional grant regression and the regional revenue. It was done by using econometric-model panel data for 33 districts in East Java Province during 2001 - 2005. By using fixed-effect model estimation, this study figured out that there was a flypaper effect indicated by the higher elasticity number of unconditional grant than of regional revenue towards the regional budget in East Java Province.
\end{abstract}

Keywords: fiscal decentralization, flypaper effect, panel data analysis JEL Classification: C23, E62

\section{INTRODUCTION}

An authority delegation to the regional government becomes an initial step to the regional autonomy. Indonesia as a democratic country has embarked the regional autonomy since the issuance of the Regulation Number 25 of 1999 and the Regulation Number 33 of 2004 on Financial Balance between Central Government and Regional Government. Despite this kind of autonomy delegation triggered by economic and political crisis (Balisacan et al., 2008), the impact on authority delegation could stimulate the economic growth (Anis \& Ardi, 2007).

Fiscal decentralization implemented by Indonesia in post-reformation era more focuses on the authority delegation of revenue and budget. The regional government as the executor of regional budget is perceived having perfect information on which sector from the budget allocation that could possibly accelerate the economic growth. In the other side, however, the regional authority on fiscal has decreased. During the regional autonomy and fiscal decentralization, the regional government acts as a tax collector under the higher government. The impact on this policy is that regional revenue is gradually diminishing, despite lower revenue converted into transfer funds provided by the central government. 
Fiscal decentralization concerning on the allocation of regional budget will lead to the allocation inefficiency (Neyapti, 2010). The regional revenue derived from the transfer of General Allocation Funds and Revenue Sharing Funds can be utilized for daily budget or others. The potency of inefficient budget use is likely to emerge from the regional authority in allocating the regional revenue, including the transfer funds.

Along with the increase of regional budget, the percentage of transfer funds proposed to the central government is steadily increasing. The regional government has an authority to increase the transfer funds proportion for their respective regions. This proportion is clearly stated in Article 27 of the Regulation Number 33 of 2004 in which the regional government could apply for additional transfer funds from fiscal gap owned by the regional government.

A region without fiscal capability in fulfilling the regional budget demands higher number of transfer funds from the central government. The fiscal gap emerged in a region may be due to the low regional revenue, the higher personnel expenses, or other factors causing the disparity between the revenue and budget. There is allegedly an inefficient allocation leading to the fiscal gap which then increases the allocation of regional transfer funds in several districts in East Java.

The financial management referring to the expenditure function creates potential inefficiency of budget allocation. The externalization in this such decentralization can be employed for several regions to take an advantage on the central government's fiscal overflow. In terms of expenditure, the authority delegation for fiscal management given by the central government to the regional government has several drawbacks: 1) the regional government could hardly achieve the economic scale in providing public goods due to higher cost of information and coordination as a result of the deficiency of institutional and administrative capacity; 2) in a case of the high number of local interest, this such decentralization could lead to massive corruption and social fragmentation due to the absence of local accountability; 3) the decentralization could increase the political tension and competition among regional governments; 4) the distinct coordination issues among different government levels could steer the deficit bias and thus restrain the fiscal reformation and the macro-economic adjustment (Neyapti, 2010).

The amount of funds given by the central government differ among regions. The higher proportion of transfer funds in the regional revenue shows the higher domination of the central government in the regional revenue. The impact of immense financial gap between the regional revenue and transfer funds from the central government increases the regional dependency in covering the fiscal gap. In terms of fiscal jurisdiction, the authority separation of taxation and budget may obscure the regional taxation assessment on both costs and benefits from public budget.

The fiscal gap covered by transfer funds is perceived easier revenue source by the regional government. Due to this assumption, the regional budget will be higher than the optimum level so that the flypaper effect will emerge as overspending indicator in the local level (Aragon, 2012). Theoretically, the budget amount provided by either central or regional government could enhance the economic growth. In short-term period, the acceleration of economic growth can indeed be triggered by consumption activities; it, however, could be optimally 
done if the allocated budget is merely addressed to the budget that is likely accelerating the economic activities.

Based on the elaborated assumption above, it can be formulated several problematics; one of which is whether the flypaper effect could happen in the regional government of several regions in East Java Province. This study aimed at investigating the flypaper effect in several regions of East Java Province during the decentralization.

\section{LITERATURE REVIEW}

The concept of fiscal decentralization aims at adjusting the principles of regional economic development based on the regional government partially financed by national budget stipulated in the transfer funds. The authority to manage the transfer funds from the central government to the regional government is expected to accelerate the regional development based on respective characters and necessities. The overview of transfer impact on the structure of regional fiscal is illustrated in the figure below:

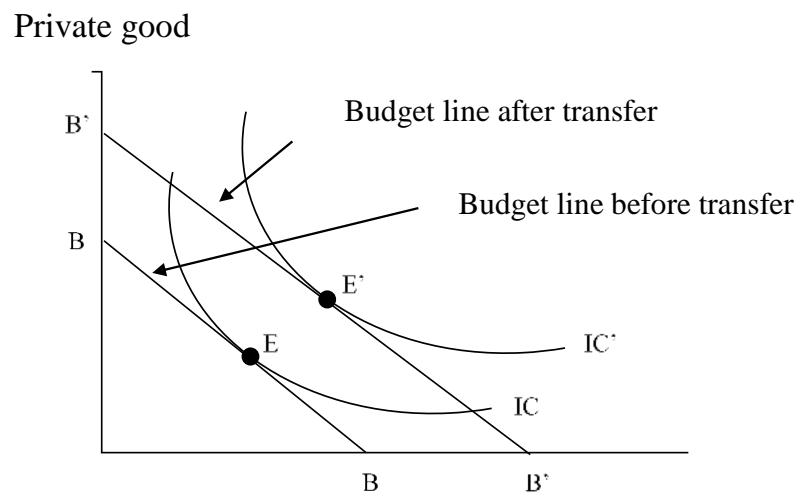

Figure 1. The Transfer Impact on the Regional Budget Source: Stiglitz (2000)

Figure 1, illustrates the transfer impact on the regional fiscal. As the concept of consumption theory where the satisfactory level on goods and services is correspondently increasing with the increase of revenue depicted by the budget line shift, the regional fiscal especially on the public and private goods can only be increased if there is a positive change in the regional fiscal. In the figure 1, the increase of regional fiscal due to the transfer funds is illustrated by budget line that is formerly on the BB line shifting into B'B' line.

The increasing regional revenue from the transfer funds provides a wide fiscal clearance so that the regional government could increase their budget to provide various public goods. The shift on E into E' line shows the shift of consumption level on the combination between public and private goods.

The increase of balanced funds which could ultimately lead to the increase of regional budget revenue can be derived from 3 major sources: sharing funds, general allocation funds, and special allocation funds. In the concept of fiscal decentralization, the increase of budget from the balanced funds derived from sharing funds mainly becomes a main purpose as well as a solid indicator of regional fiscal independency, for instance the development acceleration in a 
district could certainly improve both land and building taxes received by the central government. According to the Regulation Number 33 of 2004, 64.8\% of $90 \%$ budget is fully addressed to the regional government.

The amount of balanced funds can also be added from general allocation funds based on fiscal gap and basic allocation calculated from the total salaries of Regional Civil Servants. From the wide range of regional revenue sources apart from the Regional Own Revenue (PAD), the flypaper effect could happen if the balanced funds, especially those from non-regional revenue are higher than the increased regional revenue. Referring to the Regulation, it has also been stated that fiscal gap could be covered by the balanced funds so that the regional motivation to decrease the fiscal gap of regional own revenue (PAD) or the balanced funds from the sharing funds does not become the main reference.

The transfer policy from the central government affects not only on the decrease of budget issues encountered by a community but also on the policy efficacy due to the overacting bureaucratic behaviors in responding the financial assistance. This such perspective, furthermore, is considerably based on the empirical observation on the impact of incomes and grants towards the regional budget. The transfer expectedly lowers the tax burden on local community corresponding to the fiscal assistance from the central government; the bureaucracy, however, with its budget authority takes an advantage to set a higher budget followed by an increase of local taxes and therefore creates a fiscal phenomenon known as flypaper effect.

According to Wilde (1968); Kuncoro (2004), the flypaper effect can be recognized through the theory of consumption behaviors as illustrated in Figure 2.2 and 2.3. The transfer is noticeably classified into two types: conditional grant and unconditional grant. In conditional grant, the increase of consumption as a result of transfer acceptance is due to the price effect lowering the price of public goods and thus flatters the slope of budget line from $\mathrm{Y}$ into $\mathrm{Y}+$ transfer.

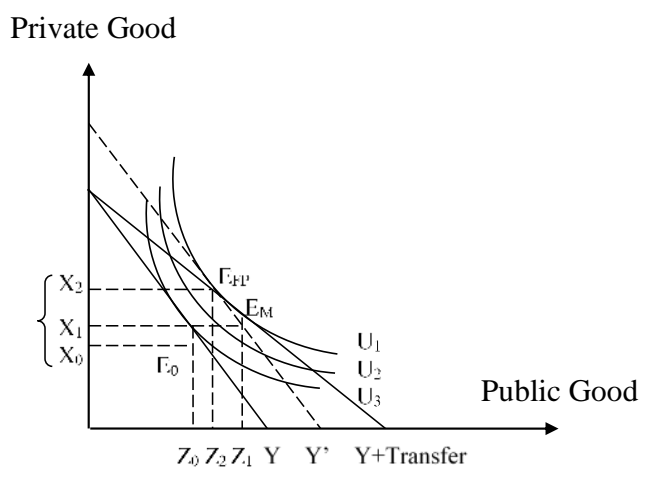

Figure 2. The Impact of Conditional Grants on Goods Consumption Source: Kuncoro (2004)

The decrease of prices heightens the consumption of public goods from $\mathrm{Z}_{0}$ to $Z_{1}$. The regional budget, moreover, will be increasing to meet the community demands for public goods. Meanwhile, the conditional grants towards the consumption of private goods solely depend on the government policy after receiving the transfer. If the transfer acceptance decreases the local taxes, the consumption of private goods, thus, will increase from $\mathrm{X}_{1}$ to $\mathrm{X}_{2}$. In this case, the 
increase of demand for both public and private goods occurs as a result of the substitution of local tax burden with the transfer acceptance from the central government.

The flypaper effect mainly occurs in the unconditional grants (Allers \& Vermeulen, 2016). This type of transfer acceptance is supposed to substitute the local tax burden leading to the increase of consumption for both public and private goods. However, in this case, the transfer occurrence does not prove the decreasing tax burden; instead, the increasing transfer acceptance occurs along with the increasing tax revenue in the regional government. Figure 2.3 illustrates the phenomena.

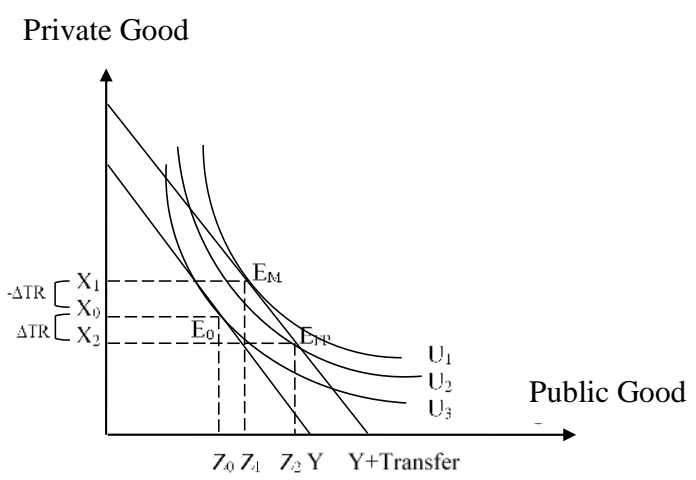

Figure 3. The Impact of Unconditional Grants on Goods Consumption Source: Kuncoro (2004)

The acceptance of unconditional grants shifts the budget line to the right of $\mathrm{Y}$ to $\mathrm{Y}+$ transfer. The decline of budget issues also shifts the consumer balance from $\mathrm{E}_{0}$ to $\mathrm{E}_{\mathrm{M}}$. In this point, the consumption of public goods is illustrated by $\mathrm{Z}_{1}$ while the consumption of the private ones is illustrated by $\mathrm{X}_{1}$. However, number of researchers figured out the anomaly illustrating that community balance after the transfer acceptance exists in $E_{F P}$ (not in $E_{M}$ ). It indicates that the transfer acceptance rather increases the local tax revenue $(+\Delta T R)$ due to the increasing consumption of public goods (from $Z_{1}$ to $Z_{2}$ ) vis-à-vis the decreasing consumption of private goods (from $X_{1}$ to $X_{2}$ ). Therefore, the flypaper effect appears as a result of the transfer acceptance that leads to the increasing consumption of public goods yet does not substitute the local taxes (Dahlby \& Ferede, 2016).

According to Tresch (2014), an empirical analysis on the flypaper effect lays on two basic principles: 1) Bureaucratic Model representing how the regional government responds the given grants to provide varied public services; and 2) Median-Voter Model representing how the median voter is supposed to respond the given grants as the way a common consumer receives an individual transfer and hence decreases the budget issues encountered.

The bureaucratic model as explained by Niskanen (1971) has to be perceived as another individual maximizing the satisfaction including salary, a number of employees, and social reputation. As an individual, a bureaucrat is indeed not in neutral position on the budget drafting process. Therefore, he tends to yield bigger services or goods than what is supposed to be and ergo seems likely to create inefficiency in the use of government's economic resources. 
The analysis (Niskenan, 1971) on bureaucratic behaviors in determining the optimal output level is illustrated in Figure 4 below:

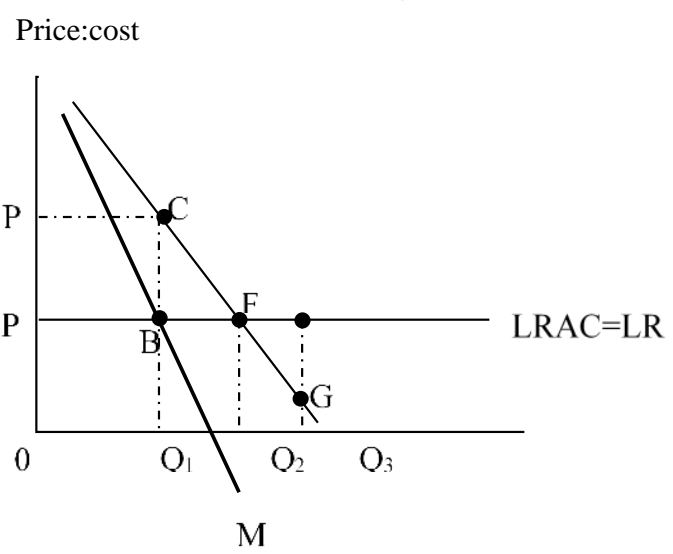

Figure 4. The Economic Analysis on Bureaucracy Source: Mangkoesoebroto (2004)

Curve CGD represents the demand curve while the curve LRMC=LRAC represents the marginal and long-period average costs assumed to have structure of constant costs. In other side, MR is the curve of acceptance marginal. If the goods are produced by private monopoly companies, the provided output level should be represented by $\mathrm{OQ}_{1}$ while its prices are represented by $\mathrm{P}_{1}$. Therefore, the obtained profits are $\mathrm{P}_{1} \mathrm{CBP}_{2}$, or the companies that do not get profits will yield the output level represented by $\mathrm{OQ}_{2}$ and its costs are represented by $\mathrm{P}_{2}$.

If the output, however, is provided by the bureaucrat under the budget authority as much as $\mathrm{OP}_{2} \mathrm{AQ}_{3}$, the obtained output will be represented by $\mathrm{OQ}_{3}$ due to the bureaucratic behaviors tending to optimize the budget; and therefore, the output provided by either monopoly companies or government could create respective welfare loss as much as CBF by monopoly companies and FAG by government. Furthermore, the phenomena of flypaper effect in the bureaucratic model appears as a result of the regional bureaucratic behaviors in over determining the regional budget, especially due to the practice of soft budget constraint from the central government in form of transfer funds or grants.

In terms of median-voter model, the flypaper effect is described through the perspective that the transfer funds are used as other revenue for an individual. Grants are supposedly allocated between local public and private goods based on revenue elasticity from median voters (Dahlberg et al., 2008). The Figure 2.4 describes the flypaper effect as adopted from Bradford a\& Oates (1971) in (Wyckoff, 1988) following the Median-Voter Model. The Figure 2.5 illustrates the impact of unconditional grants as much as A which results the shift of medianvoter budget line to the top right but does not influence the slope of budget line (T). Due to the static slope of tax share in pre and post transfer funds, the increasing revenue from transfer funds leads to the shift of budget balance between public and private goods. This could happen if the voter's preferences are free from varied properties of budget constraint. In this perspective, the increasing transfer A triggers the increase of regional revenue TA. 


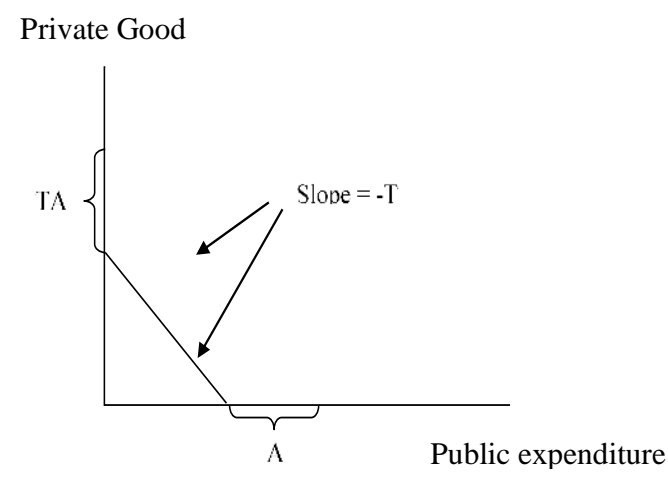

Figure 5. Median-Voter Model

Source: Wyckoff (1985)

In the other side, however, the median voter is supposed to be an individual actively participating the local decision-making process who could call demand for varied community resources (including the general assistance from the central government) as his rights. If the assistance is used to lower the local taxes, this individual will receive higher $\mathrm{T}$ number from the post-transfer revenue. By acting as the dominant actor in local politics, the median voter could favorably shift the resources inside or outside the public sector by converting the transfer proportion equal to the public budget and the burdened tax rates (Stiglitz, 2000a).

A study by Kuncoro (2004) investigating the transfer impact on fiscal performance of the regional governments in Indonesia figures out that the increasing transfer allocation is followed by the higher budget growth due to the inefficiency of regional budget, especially in routine budget. Implicitly, this indicates the higher authority for the regional government to allocate the transfer funds from the central government, especially for the unconditional grants as one of the causes for the irrelevant use of fiscal assistance whether in terms of the number and type of budgets.

In analyzing the regional budget (Kuncoro, 2004), the econometrical approach with the data from districts in Indonesia during 1988 - 2002 should be used to classify the budget into two types: 1) routine budgets; and 2) development budgets. These two variables are used as the dependent variables while the acceptance from varied types of transfer, population, income level, district's characteristics, and institutional factors as the control variables. Econometrically, it can be formulated as follows:

$$
\begin{gathered}
\Delta R E_{i t}=d_{1} \Delta U G_{i t}+d_{2} \Delta C G_{i t}+d_{3} \Delta \text { Pop }_{i t}+d_{4} \Delta Y_{i t}+d_{5} \Delta R E_{i t-1}+d_{6} D A U G+d_{7} D A C G \\
+d_{8} \text { Dkota }+d_{9} \text { Dkrisis }+d_{10} \text { Dodf }+d_{11} E C T_{4 i t-1+}
\end{gathered}
$$

and

$$
\begin{aligned}
\Delta D E_{i t}=e_{1} \Delta U G_{i t} & +e_{2} \Delta C G_{i t}+e_{3} \Delta \text { Pop }_{i t}+e_{4} \Delta Y_{i t}+e_{5} \Delta D E_{i t-1}+e_{6} D A U G+e_{7} D A C G \\
& +e_{8} \text { Dkota }+e_{9} \text { Dkrisis }+e_{10} \text { Dodf }+e_{11} E_{C T} T_{5 i t-1+} \\
& +\mu_{5 i t} \ldots \ldots \ldots \ldots \ldots \ldots \ldots \ldots \ldots \ldots \ldots \ldots(2.2)
\end{aligned}
$$

In which, $\mathrm{RE}$ is the routine budget and $\mathrm{DE}$ is the development budget. This study (Kuncoro, 2004) indicates the occurrence of flypaper effect in the regional budget in which the increasing unconditional grants are perceived by the regional government by utilizing the Regional Own Revenue (PAD). 
Furthermore, Widarjono (2006) explains that the regional budget and the occurrence of flypaper effect by using province-level data during 1995 - 2002 as one of the bureaucratic behaviors in setting or determining the budget. To perceive this flypaper effect phenomena, Widarjono (2006) describes the regional budget as the function of Regional Own Revenue (Y), Transfer Funds or Grants (Tr), and Population (Pop) and detects the occurrence of flypaper effect based on the comparison between the value of coefficient $\beta_{1}$ and $\beta_{2}$ from the equation 2.3 below:

and

$$
\begin{aligned}
& \Delta R E_{i t}=d_{1} \Delta U G_{i t}+d_{2} \Delta C G_{i t}+d_{3} \Delta \text { Pop }_{i t}+d_{4} \Delta Y_{i t}+d_{5} \Delta R E_{i t-1}+d_{6} D A U G+d_{7} D A C G \\
& +d_{8} \text { Dkota }+d_{9} \text { Dkrisis }+d_{10} \text { Dodf }+d_{11} E C T_{4 i t-1+}
\end{aligned}
$$

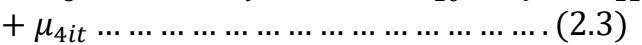

$$
\begin{aligned}
& \Delta D E_{i t}=e_{1} \Delta U G_{i t}+e_{2} \Delta C G_{i t}+e_{3} \Delta P o p_{i t}+e_{4} \Delta Y_{i t}+e_{5} \Delta D E_{i t-1}+e_{6} D A U G+e_{7} D A C G \\
& +e_{8} \text { Dkota }+e_{9} \text { Dkrisis }+e_{10} \text { Dodf }+e_{11} E C T_{5 i t-1+}
\end{aligned}
$$

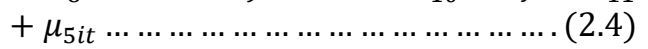

The Widarjono's analysis (2006) shows that the occurrence of flypaper effect with regression coefficient $\beta_{1}>\beta_{2}$ can be described through the bureaucratic model that significantly uses its authority in over setting or determining the budget policy due to the transfer funds. Meanwhile, a study by Iskandar (2012) identifies the response of regional budget on unconditional grants by using district-level data during 2004 - 2008 in West Java Province. This study figures out that there is no flypaper effect. The model used in this study is presented as follows:

$B D_{i t}=b_{0}+b_{1} U G_{i t}+b_{2} P A D_{i t}+b_{3} P D R B_{i t}+\mu_{i t}$

The estimation result of the equation 2.6 shows the response of regional budget as a result of the increase of Regional Own Revenue (PAD) that is higher than the transfer funds of central government. Therefore, there is no flypaper effect in the regional budget of West Java Province. A study conducted by Wyckoff (1985) examines the bureaucratic model in explaining the flypaper effect on the budget of several districts in Michigan 1970 by using this following model (2.7):

$$
\begin{aligned}
\ln E & =b_{0}+b_{1} \ln \text { Pop }+b_{2} \ln T+b_{3} \ln Z+b_{4} I N C R A T I O+b_{5} \operatorname{lnOTHERAID} \\
& +b_{6} \text { DENSITY }+b_{7} \text { PEROWN }+b_{8} \text { PERNOWN }+b_{9} \text { PER } 65 A O+\varepsilon .(2.7)
\end{aligned}
$$

In which E represents all types of budget in the regional government unless for water, electricity, gas, and transportation services. Pop is a city population, $\mathrm{T}$ is tax share, $\mathrm{Z}$ represents the total revenues of median vote, ICRATIO is a revenue proportion obtained from sharing revenue (T), DENSITY represents the population density, PEROWN represents a percentage of citizens who have their own house, PERNOWN represents non-white population, and PER65AO represents total population aged above 65 years old.

This study offers significant contribution, especially in terms of recognizing how the existing theoretical concept could explain the flypaper effect in the regional budget. The existence of bureaucratic authority in setting or determining the regional budget is examined by using two methodologies comprising parameter $b_{1}$ and $b_{4}$. Coefficient $b_{1}$ shows the population elasticity 
towards the regional budget reflecting the budget response on the cost of providing public services as the representation of bureaucratic model about flypaper effect. Meanwhile, the coefficient $b_{4}$ shows the elasticity of grants acceptance portion as a part of individual revenues towards the regional budget representing the median-vote model.

\section{METHOD}

This study aimed at investigating the flypaper effect phenomena during the fiscal decentralization era by using the OLS approach with the secondary data derived from the Statistical Bureau (BPS), the Directorate General of Regional Fiscal Balance and the Directorate General of Regional Fiscal, and other relevant sources. The data in this study were Regional Own Revenue including Regional Tax Revenue, APBD, PDRB, Indonesian Statistics, Population, and other relevant data. This study, moreover, was conducted from 2012 to 2014 in 38 districts of East Java Province.

It concerned on the flypaper effect in several districts of East Java Province with the secondary data comprising regional budget, general allocation funds, tax-sharing funds, density, and regional own revenue. The analysis was done by means of econometrical approach with the panel data aiming at describing the pattern of district budget in East Java Province. To detect the occurrence of flypaper effect, it was used the model development from three previous studies (Iskandar, 2012; Widarjono, 2006; Wyckoff, 1988). Further, the econometric model developed from the referred model is formulated as follows:

$$
\begin{gathered}
\ln P L=b_{0}+b_{1} \ln p o p+b_{2} \ln U G+b_{3} \ln P A D+b_{4} \ln P D R B+\varepsilon \\
P t L=b_{0}+b_{1} \quad \text { pop }+b_{2} U G+b_{3} P A D+b_{4} P D R B+\varepsilon
\end{gathered}
$$

PL represents the total of direct regional budgets while PtL represents the indirect budgets. UG is the unconditional grants consisting of General Allocation Funds (DAU) and Tax-Sharing Funds (DBHP). PAD represents the regional own revenue and PDRB represents gross regional domestic products. Last, density represents the population density in every district.

Considering numerous estimation techniques for the panel model, several statistical analyses were conducted in this study, such as: Chow-test and Hausman-test to get more suitable model as probe. Chow-test was used to determine whether the model is better estimated by using model of pooled least square or fixed effect. Meanwhile, the Hausman-test was used to choose either fixed effect or random effect approach as the relevant method. The hypothesis of Chow-test is formulated as follows:

$\mathrm{H}_{0}$ : Pooled Least Square model

$\mathrm{H}_{1}$ : Fixed Effect model

The decision on above hypothesis was done by comparing the F-statistical calculation with F-table. The comparison would be used if the F-result was higher than F-table; and ergo, the $\mathrm{H}_{0}$ was rejected and the Fixed Effect model had to be used as the suitable model. Meanwhile, the Hausman-test was formulated under this following hypothesis:

$\mathrm{H}_{0}:$ Random Effect model (REM)

$\mathrm{H}_{1}:$ Fixed Effect model (FEM) 
If, furthermore, the chi square value $>$ the chi square table, the p-value would be significant and thus $\mathrm{H}_{0}$ was rejected and the Fixed Effect model had to be used.

\section{RESULT AND DISCUSSION}

To obtain the best model, the Lagrange Multiplier test was used. The result of LM test showed that pooled model was better applied to the spatial econometrics, either for spatial lag or spatial error. This conclusion was determined from the $\alpha$-value $=0.05$.

Table 1. LM-Test

\begin{tabular}{|ll}
\hline LM-Test & Probability value \\
\hline LM Lag & $34.471^{* *}$ \\
\hline LM error & $18.773^{* *}$ \\
\hline Robust LM lag & $27.432 * *$ \\
\hline Robust LM lag & $22.712^{* *}$ \\
\hline
\end{tabular}

Source: processed data

** Significant at $\alpha 0,05$

* Significant at $\alpha 0,01$
Table 2. Hausman-Test

\begin{tabular}{l}
\hline \multicolumn{1}{c}{ Statistic value } \\
\hline Hausman for spatial \\
lag
\end{tabular}

After selecting the best model, the next phase was determining whether fixed effect was better than random effect by using Hausman-test. From the result of the test, it was gained that the appropriate panel model for both spatial lag and error was random effect due to their insignificant probability values.

The $\mathrm{R}^{2}$ test was used to investigate the estimated regression model. The $\mathrm{R}^{2}$ value of panel model in spatial lag could demonstrate its ability in explaining the variable $\mathrm{Y}$. The $\mathrm{R}^{2}$ value gained in this test was 0.999 or $99.9 \%$ which indicated that variable $\mathrm{X}$ could explain variable $\mathrm{Y}$.

The selection of Fixed Effect method as the best model based on Chowtest necessarily required the next probe for the equation 3.1 by using random effect. Further, it compared two methods to yield the best model based on Huasman-test. The estimation result by using Random Effect is illustrated in the table below:

Table 3. Regression Output with Fixed Effect Method

\begin{tabular}{lcc}
\hline \multicolumn{1}{c}{ Variable } & Coefficient & Standard Error \\
\hline C & $0,573932^{*}$ & 0,332336 \\
\hline PAD & $0,052872^{*}$ & 217.8177 \\
\hline UG & $0.012891^{*}$ & 7.684174 \\
\hline POP & $0.035507^{*}$ & 105.6116 \\
\hline PDRB & $-0.007665^{*}$ & -30.78134 \\
\hline F-statistic & 0,0000000 & \\
\hline $\mathbf{R}^{2}$ & 0,999749 & \\
\hline $\mathbf{N}$ & 111 & \\
\hline
\end{tabular}

Note: * significant regression coefficient at $\alpha=1 \%$

Regression output showed the determination coefficient $\mathrm{R}^{2}=0.99$ indicating that $99 \%$ variation of the district budget in East Java Province can be explained by the shift of unconditional grants, Regional Own Revenue (PAD), Gross Regional Domestic Product (PDRB), and Population (Pop). Therefore, the 
model was perceived good to explain the pattern of regional budget supported by the probability value of F-statistic that is lower than alpha value 0.05 . Besides, the regression with random effect resulted the consistent parameter coefficient under the OLS technique in which the UG, PAD, PDRB variables significantly influenced the regional budget under the credibility interval $\alpha=1 \%$. Meanwhile, the population did not significantly influence the regional budget as what had been described in the regression result by using Fixed Effect method.

The unconditional grants significantly influenced the district budget in East Java Province 2012 - 2015. The value of regression coefficient 0.012891 indicating that the increase of unconditional grants by $1 \%$ (ceteris paribus assumption) by the regional government will increase the district budget in East Java Province by $0.012891 \%$. The significant impact of unconditional grants on the regional budget related to the findings of previous studies (Wyckoff, 1985; Kuncoro, 2004; Widarjono, 2006; Iskandar, 2012).

The description of correlation between the transfer funds from the central government and the regional budget relied on the budget sources in which the transfer funds was one component of the regional budget sources. As a budget source, the transfer funds from the central government acted as the major component of district budget source in East Java Province. This fact can be elaborated through this following table:

Table 4. Transfer Ratio towards Total Acceptance Districts in East Java Province

\begin{tabular}{|c|c|c|c|c|c|c|c|c|c|}
\hline District & 2012 & 2013 & 2014 & 2015 & District & 2012 & 2013 & 2014 & 2015 \\
\hline Bangkalan & $67 \%$ & $62 \%$ & $62 \%$ & $58 \%$ & Pamekasan & $67 \%$ & $66 \%$ & $57 \%$ & $52 \%$ \\
\hline Banyuwangi & $67 \%$ & $66 \%$ & $59 \%$ & $55 \%$ & Pasuruan & $67 \%$ & $67 \%$ & $54 \%$ & $52 \%$ \\
\hline Blitar & $67 \%$ & $62 \%$ & $60 \%$ & $56 \%$ & Ponorogo & $68 \%$ & $68 \%$ & $62 \%$ & $59 \%$ \\
\hline Bojonegoro & $81 \%$ & $70 \%$ & $69 \%$ & $71 \%$ & Probolinggo & $67 \%$ & $71 \%$ & $64 \%$ & $56 \%$ \\
\hline Bondowoso & $68 \%$ & $113 \%$ & $63 \%$ & $57 \%$ & Sampang & $70 \%$ & $71 \%$ & $69 \%$ & $61 \%$ \\
\hline Gresik & $60 \%$ & $50 \%$ & $47 \%$ & $42 \%$ & Sidoarjo & $52 \%$ & $50 \%$ & $46 \%$ & $38 \%$ \\
\hline Jember & $67 \%$ & $65 \%$ & $59 \%$ & $57 \%$ & Situbondo & $73 \%$ & $66 \%$ & $60 \%$ & $59 \%$ \\
\hline Jombang & $69 \%$ & $65 \%$ & $60 \%$ & $55 \%$ & Sumenep & $77 \%$ & $77 \%$ & $68 \%$ & $61 \%$ \\
\hline Kediri & $71 \%$ & $72 \%$ & $61 \%$ & $54 \%$ & Trenggalek & $69 \%$ & $69 \%$ & $73 \%$ & $59 \%$ \\
\hline Lamongan & $64 \%$ & $66 \%$ & $64 \%$ & $56 \%$ & Tuban & $68 \%$ & $69 \%$ & $61 \%$ & $55 \%$ \\
\hline Lumajang & $73 \%$ & $72 \%$ & $61 \%$ & $55 \%$ & Tulungagung & $61 \%$ & $67 \%$ & $72 \%$ & $54 \%$ \\
\hline Madiun & $69 \%$ & $70 \%$ & $65 \%$ & $60 \%$ & Blitar & $71 \%$ & $68 \%$ & $69 \%$ & $64 \%$ \\
\hline Magetan & $72 \%$ & $72 \%$ & $63 \%$ & $58 \%$ & Kediri City & $72 \%$ & $77 \%$ & $61 \%$ & $59 \%$ \\
\hline Malang & $65 \%$ & $68 \%$ & $59 \%$ & $54 \%$ & Madiun City & $78 \%$ & $68 \%$ & $64 \%$ & $56 \%$ \\
\hline Mojokerto & $64 \%$ & $64 \%$ & $55 \%$ & $48 \%$ & Malang City & $64 \%$ & $56 \%$ & $54 \%$ & $52 \%$ \\
\hline Nganjuk & $68 \%$ & $69 \%$ & $65 \%$ & $54 \%$ & Mojokerto City & $74 \%$ & $78 \%$ & $66 \%$ & $60 \%$ \\
\hline Ngawi & $75 \%$ & $71 \%$ & $69 \%$ & $59 \%$ & Probolinggo city & $70 \%$ & $71 \%$ & $64 \%$ & $58 \%$ \\
\hline \multirow[t]{2}{*}{ Pacitan } & $68 \%$ & $68 \%$ & $68 \%$ & $61 \%$ & Surabaya City & $32 \%$ & $28 \%$ & $24 \%$ & $21 \%$ \\
\hline & & & & & Batu City & $86 \%$ & $77 \%$ & $60 \%$ & $56 \%$ \\
\hline
\end{tabular}

Source: Data Processed, 2016

During 2012 - 2015, the transfer contribution on the district budget in East Java Province ranged from 26 to $71 \%$ of the total regional budgets. The amount of unconditional grants towards the total district revenue made this variable dependent in the budget structure. Averagely, more than $70 \%$ of the district budget in East Java Province was funded by transfer funds from the central government in form of the general allocation funds and tax-sharing funds. In the other side, the decentralization practice merely focusing on the budget function in 
the lack condition of regional fiscal brought huge consequence for the central government in managing the transfer policy to decrease the gap between regional revenue and budget. This attempt was indeed their responsibility in implementing the fiscal decentralization policy in accordance with the regional autonomy.

In the micro-economy concept, the consumer's behaviors on how they maximize the utilization of public goods provided by the regional government can be perceived as the community's satisfaction towards the regional government in fulfilling the community's necessities, for instance: hospital, roadway, public facilities, and government services in varied sectors.

The provision of both public goods and services was from the regional budget. The higher revenue the regional government could obtain, the higher potency of the regional budget would be. Hence, it is expected that the regional government could shift their budge mainly to the provision of public goods. As illustrated in Figure 2.2, the higher budget the regional government could set including those from transfer funds, the lower price of public goods must be; therefore, the community consumption on the public goods could increase and ultimately improve its utilization.

\section{CONCLUSION}

Based on the discussion above, it can be concluded that there was a flypaper effect in the regional budget in East Java Province during 2012 - 2015. It was indicated by the elasticity of unconditional grants that was higher than the elasticity of Regional Own Revenue (PAD) towards the regional budget. Intuitively, the higher transfer elasticity represented the responsive regional bureaucracy on the shift of transfer acceptance to increase the budget compared to the regional own revenue. The excessive bureaucratic behaviors will always demand the increase of transfer acceptance despite the steady mobilization of internal funds. Following the bureaucratic model, flypaper effect in the regional budget in East Java Province was mainly caused by the dominant transfer funds from the central government in the structure of regional revenue which therefore leads to the regional bureaucracy. In this case, the regional government with their budget authority seems to be more responsive towards the transfer acceptance. The perspective on excessive bureaucratic behaviors tending to yield the higher output than the optimal level supported by the budget probability in the balanced fiscal scheme, especially for the general allocation funds and tax-sharing funds, offered the regional authority in allocating the budget. Considering the findings of this study that illustrate the significant impact of population towards the regional budget in East Java Province, the correlation transmission for these both variables, especially in a case of transfer funds from the central government, had considered the population variable in the calculation analysis. The regional government is expected to steadily increase the regional taxes despite the increase of transfer funds from the central government. Besides, the authority separation of revenue and budget between the central and regional government in the decentralization practice emerges as another important issue of flypaper effect due to the limitations of regional government in mobilizing the internal funds. 


\section{REFERENCES}

Allers, M.A., \& Vermeulen, W. (2016). Capitalization of Equalizing Grants and the Flypaper Effect. Regional Science and Urban Economics, 58, 115-129.

Anis, S., \& Ardi, H. (2007). Pengaruh PAD, DAU, DAK, dan Belanja Pembangunan Terhadap Pertumbuhan Ekonomi, Kemiskinan, dan Pengangguran: Pendekatan Analisis Jalur. Jurnal Akuntansi dan Keuangan Indonesia, 4(2), 211-228.

Aragon, F. (2012). Local spending, transfers and costly tax collection.

Balisacan, A. M., Hill, H., \& Piza, S. F. (2008). Regional development dynamics and decentralization in the Philippines: ten lessons from a fast starter. ASEAN Economic Bulletin, 25(3), 293-315.

Dahlberg, M., Mörk, E., Rattsø, J., \& Ågren, H. (2008). Using a discontinuous grant rule to identify the effect of grants on local taxes and spending. Journal of Public Economics, 92(12), 2320-2335.

Dahlby, B., \& Ferede, E. (2016). The stimulative effects of intergovernmental grants and the marginal cost of public funds. International Tax and Public Finance, 23(1), 114-139.

Iskandar, I. (2012). Flypaper Effect pada Unconditional Grant. Jurnal Ekonomi Pembangunan, 13(1), 113-131.

Kuncoro, H. (2004). Pengaruh transfer antar pemerintah pada kinerja fiskal pemerintah daerah kota dan kabupaten di Indonesia. Jurnal Ekonomi Pembangunan, 9(1), 47-63.

Kuncoro, M. (2004). Teori Mikroekonomi. Jakarta: Erlangga.

Mangkoesoebroto, G. (2004). Ekonomi Publik. Yogyakarta : BPFE - Yogyakarta.

Neyapti, B. (2010). Fiscal decentralization and deficits: International evidence. European Journal of Political Economy, 26(2), 155-166.

Niskanen, W. A. (1971). Bureaucracy and representative government: Transaction Publishers.

Regulation Number 25 of 1999 on Central and Regional Financial Balance. Retrieved from http://www.djpk.depkeu.go.id/?p=341.

Regulation Number 33 of 2004 About Financial Considerations Between The Central Government And Regional Government retrieved from https://luk.staff.ugm.ac.id/atur/UU33-2004PerimbanganKeuanganLengkap .pdf.

Stiglitz, J. E. (2000a). Capital market liberalization, economic growth, and instability. World development, 28(6), 1075-1086.

Stiglitz, J.E. (2000). The Contributions of the Economics of Information to Twentieth Century Economics. The Quarterly Journal of Economics, 115(4), 1441-1478.

Tresch, R. W. (2014). Public finance: A normative theory: Academic Press.

Widarjono, A. (2006). Does Intergovernmental Transfers Cause Flypaper effect on Local Spending? Economic Journal of Emerging Markets, 11(2).

Wilde, J. A. (1968). The expenditure effects of grant-in-aid programs. National Tax Journal, 21(3), 340-348.

Wyckoff, P. G. (1988). A bureaucratic theory of flypaper effects. Journal of Urban Economics, 23(1), 115-129. 